\title{
Analisis Terhadap Sistem Pembagian Harta Warisan
}

\author{
Muhammad Asykur Muchtar \\ Fakultas Hukum, Universitas Muhammadiyah Sorong \\ E-mail: asykurs.hi@gmail.com
}

\begin{abstract}
Abstrak
Penelitian ini bertujuan untuk mengetahui perbedaan antara sistem hukum kewarisan Islam, Adat dan perdata serta faktor-faktor yang mempengaruhi dalam proses pembagian harta warisan apakah terdapat banyak perbedaan antara ketiganya.

Metode penelitian yang digunakan merupakan penelitian hukum normatif. Teknik pengumpulan data dilakukan dengan cara mengumpulkan data-data melalui buku-buku yang relevan dengan penelitian.

Hasil penelitian menunjukkan bahwa sistem hukum kewarisan Islam, Adat dan Perdata memiliki beberapa perbedaan yaitu bagian yang didapatkan para ahli waris berbeda satu sama lain.salah satu contoh yaitu pembagian harta warisan menurut hukum Islam, bagian ahli waris laki-laki dau bagian dari bagian ahli waris perempuan dimana dalam hukum kewarisan Adat bagian ahli waris seimbang atau sama rata antara ahli waris laki-laki maupun ahli waris perempuan.
\end{abstract}

Kata Kunci : Analisis, Sistem Pembagian Harta Warisan

\section{PENDAHULUAN}

Hukum waris merupakan salah satu dari hukum perdata secara keseluruhan dan merupakan bagian terkecil dari hukum kekeluargaan. Hukum waris sangat erat kaitannya dengan ruang lingkup kehidupan manusia, sebab setiap manusia pasti akan mengalami peristiwa hukum yang dinamakan kematian. Akibat hukum yang selanjutnya timbul dengan terjadinya peristiwa hukum kematian seseorang, diantaranya ialah masalah bagaimana pengurusan dan kelanjutan hak-hak dan kewajiban-kewajiban seseorang yang meninggal dunia tersebut.

Oleh karena itu, Pembagian harta warisan bagi orang yang ditinggalkan sudah menjadi ketetapan umum. Akan tetapi sebelum Islam datang pembagian tersebut belum sepenuhnya dikatakan adil. Hal ini disebabkan belum adanya ketetapan secara pasti siapa saja yang berhak mendapatkan harta warisan. Bahkan, pada zaman jahiliyah, wanita yang 
tidak memiliki andil besar dalam perjuangan tidak mendapatkan bagian. Bahkan, para wanita dijadikan tumbal dan dibunuh secara keji karena dianggap tidak memberikan kontribusi yang baik bagi keluarganya, selain dianggap sebagai pembawa mudharat. Oleh karena itu Islam datang dan memperbaiki semua itu. Setelah Islam datang, ketetapan ahli waris pun menjadi jelas. Hal ini tidak diragukan lagi bahwa ternyata Islam sangat teliti dan cermat dalam masalah penghitungan warisan. Tidak hanya bagian anak dan saudara yang memiliki hubungan darah langsung dari mayit yang diperhatikan, tetapi saudara jauh bahkan ahli waris yang tidak mendapatkan warisan dan sebab-sebab mereka tidak mendapatkan warisan pun dijelaskan secara lengkap dan jelas.

Di Indonesia hukum waris adat bersifat pluralistik menurut suku bangsa atau kelompok etnik yang ada. Pada dasarnya hal itu disebabkan oleh sistem garis keturunan yang berbeda-beda, yang menjadi dasar dari sistem suku-suku bangsa atau kelompokkelompok etnik.

Dalam prakteknya ditengah masyarakat masih banyak dijumpai praktek pembagian harta warisan yang menyalahi atau tidak mengikuti peraturan-peraturan yang telah ada, baik itu hukum kewarisan Islam maupun hukum kewarisan Adat. Hal inilah yang dapat menimbulkan perselisihan diantara ahli waris dalam pembagian harta warisan. Berdasarkan uraian tersebut diatas maka dapat dirumuskan masalah pokok sebagai berikut :(a)Bagaimanakah sistem pembagian harta waris menurut hukum Islam, adat, dan perdata? (b)Faktor-faktor apakah yang mempengaruhi pelaksanaan pembagian harta waris?

\section{PEMBAHASAN}

Kepastian yang pasti dihadapi oleh manusia di dunia adalah kepastian yang menyatakan bahwa semua manusia akan meninggal dunia. Sewaktu ia masih hidup sebagai anggota masyarakat disertai hak dan kewajiban terhadap orang, misalnya terhadap sanak saudara yang ditinggalkan. Dan sebagaimana diketahui terdapat bermacam-macam perhubungan hukum menyangkut meninggalnya seseorang, menyangkut tentang harta benda, yang pada hakikatnya akan berpindah kepada orang lain. Kematian seseorang sudah jelas tidak melenyapkan perhubungan hukum tersebut. Sehingga dalam kenyataannya diperlukan cara dan bagaimana hak dan kewajiban yang menyangkut harta benda saat yang bersangkutan meninggal dunia akan berpindah kepada orang yang masih hidup. Karena itulah umumnya masyarakat menghendaki adanya suatu peraturan yang menyangkut harta benda yang ditinggalkan setelah ia meninggal dunia. 
Sampai sekarang ini, hukum waris yang berlaku untuk mengatur pewarisan di Indonesia masih beraneka ragam, terdapat tiga sistem hukum yang mengatur masalah warisan, yaitu hukum Islam, hukum Adat dan hukum perdata barat (BW). Berdasarkan uraian diatas, mari kita lihat bagaimana sistem pembagian dari ketiga sistem hukum tersebut.

\section{Sistem Pembagian Harta Waris Menurut Hukum Islam}

Harta warisaan, merupakan harta yang diberikan dari orang yang telah meninggal kepada orang-orang terdekatnya seperti keluarga dan kerabat-kerabatnya. Pembagian harta waris dalam Islam telah begitu jelas diatur dalam al qur an, yaitu pada surat An Nisa. Allah dengan segala rahmat-Nya, telah memberikan pedoman dalam mengarahkan manusia dalam hal pembagian harta warisan. Pembagian harta ini pun bertujuan agar di antara manusia yang ditinggalkan tidak terjadi perselisihan dalam membagikan harta waris.

Harta waris dibagikan jika memang orang yang meninggal meninggalkan harta yang berguna bagi orang lain. Namun, sebelum harta waris itu diberikan kepada ahli waris, ada tiga hal yang terlebih dahulu mesti dikeluarkan, yaitu peninggalan dari mayit:

(a) Segala biaya yang berkaitan dengan proses pemakaman jenasa;(b) Wasiat dari orang yang meninggal; dan (c) Hutang piutang sang mayit.

Ketika tiga hal di atas telah terpenuhi barulah pembagian harta waris diberikan kepada keluarga dan juga para kerabat yang berhak.

Adapun besar kecilnya bagian yang diterima bagi masing-masing ahli waris dapat dijabarkan sebagai berikut:

Pembagian harta waris dalam Islam telah ditentukan dalam al-qur'an surat an nisa secara gamblang dan dapat kita simpulkan bahwa ada 6 tipe persentase pembagian harta waris, ada pihak yang mendapatkan setengah (1/2), seperempat (1/4), seperdelapan (1/8), dua per tiga (2/3), sepertiga (1/3), dan seperenam (1/6).

Hukum Kewarisan menurut hukum Islam sebagai salah satu bagian dari hukum kekeluargaan (Al ahwalus Syahsiyah) sangat penting dipelajari agar supaya dalam pelaksanaan pembagian harta warisan tidak terjadi kesalahan dan dapat dilaksanakan dengan seadil-adilnya, sebab dengan mempelajari hukum kewarisan Islam maka bagi ummat Islam, akan dapat menunaikan hak-hak yang berkenaan dengan harta warisan setelah ditinggalkan oleh muwarris (pewaris) dan disampaikan kepada ahli waris yang berhak untuk menerimanya. Dengan demikian seseorang dapat terhindar dari dosa yakni 
tidak memakan harta orang yang bukan haknya, karena tidak ditunaikannya hukum Islam mengenai kewarisan. Hal ini lebih jauh ditegaskan oleh rasulullah Saw. Yang artinya:

“Belajarlah Al Qur'an dan ajarkanlah kepada manusia, dan belajarlah faraidh dan ajarkanlah kepada manusia, karena sesungguhnya aku seorang yang akan mati, dan ilmu akan terangkat, dan bisa jadi akan ada dua orang berselisih, tetapi tak akan mereka bertemu seorang yang akan mengabarkannya (HR. Ahmad Turmudzi dan An Nasa' '").

Berdasarkan hadits tersebut di atas, maka ilmu kewarisan menururt Islam adalah sangat penting, apalagi bagi para penegak hukum Islam adalah mutlak adanya, sehingga bisa memenuhi harapan yang tersurat dalam hadits rasulullah di atas.

Dalam pasal 171 Kompilasi Hukum Islam, ada beberapa ketentuan mengenai kewarisan ini, yaitu: (a)hukum kewarisan adalah hukum yang mengatur tentang pemindahan hak pemilikan harta peninggalan (tirkah) pewaris, menentukan siapa-siapa yang berhak menjadi ahli waris dan berapa bagiannya masing-masing. (b) Pewaris adalah orang yang pada saat meninggal berdasarkan putusan Pengadilan beragama Islam, meninggalkan ahli awaris dan harta peninggalan. (c) Ahli waris adalah orang yang pada saat meninggal dunia mempunyai hubungan darah atau hubungan perkawinan dengan pewaris, beragama Islam dan tidak terhalang karena hukum unutk menjadi ahli waris. (d) Harta peninggalan adalah harta yang ditinggalkan oleh pewaris baik yang berupa harta benda yang menjadi hak miliknya maupun hak-haknya. (e) Harta warisan adalah harta bawaan ditambah bagian dari harta bersama setelah digunakan untuk keperluan pewaris selama sakit sampai meninggalnya, biaya pengurusan jenazah, pembayaran hutang dan pemberian untuk kerabat. (f) Wasiat adalah pemberian suatu benda dari pewaris kepada orang-orang lain atau lembaga yang akan berlaku setelah pewaris meninggal dunia. (g) Hibah adalah pemberian suatu benda secara sukarela dan tanpa imbalan dari seseorang kepada orang lain yang masih hidup untuk dimiliki. (h) Baitul Maal adalah balai harta keagamaan.

Sedang kewajiban ahli waris terhadap pewaris menurut ketentuan pasal $175 \mathrm{KHI}$ adalah: (a) Mengurus dan menyelesaikan sampai pemakaman jenazah selesai. (b) Menyelesaikan baik hutang-hutang berupa pengobatan, perawatan termasuk kewajiban pewaris maupun menagih piutang. (c) Menyelesaiakan wasiat pewaris. (d) Membagi harta warisan diantara ahli waris yang berhak.

Para ahli waris baik secara bersama-sama atau perseorangan dapat mengajukan permintaan kepada ahli waris yang tidak menyetujui permintaan itu, maka yang 
bersangkutan dapat mengajukan gugatan melalui Pengadilan Agama untuk dilakukan pembagian harta warisan (pasal $188 \mathrm{KHI}$ ).

Bila pewaris tidak meninggalkan ahli waris sama sekali, atau ahli warisnya tidak diketahui ada atau tidaknya, maka harta tersebut atas putusan Pengadilan Agama diserahkan penguasaannya kepada Baitul Maal untuk kepentingan agama Islam dan kesejahteraan umum (Pasal $191 \mathrm{KHI})$.

Bagi pewaris yang beristeri lebih dari seorang, maka masing-masing isteri berhak mendapat bagian dagi gono-gini dari rumah tangga dengan suaminya sedangkan keseluruhan bagian pewaris adalah menjadi hak milik para ahli warisnya (Pasal 190 $\mathrm{KHI})$.

Duda mendapat separuh bagian, bila pewaris tidak meninggalkan anak, dan bila pewaris meninggalkan anak, maka duda mendapat seperempat bagian (Pasal $179 \mathrm{KHI}$ ).

Janda mendapat seperempat bagian, bila pewaris tidak meninggalkan anak, dan apabila pewaris meninggalkan anak, maka janda mendapat seperempat bagian (Pasal 180 $\mathrm{KHI})$.

Masalah waris mewarisi dikalangan ummat Islam di Indonesia, secara jelas diatur dalam pasal 49 Undang-undang Nomor 7 Tahun 1989, bahwa Pengadilan Agama berwenang memeriksa, memutus dan menyelesaikan perkara-perkara kewarisan baik ditingkat pertama antara orang-orang yang beragama Islam dibidang: (a) Perkawinan. (b) Kewarisan, wasiat dan hibah yang dilakukan berdasarkan hukum Islam. (c) Wakaf dan sedekah.

Menurut hukum Islam hak waris itu diberikan baik kepada keluarga wanita (anak-anak perempuan, cucu-cucu perempuan, ibu dan nenek pihak perempuan, saudara perempuan sebapak seibu, sebapak atau seibu saja). Para ahli waris berjumlah 25 orang, yang terdiri dari 15 orang dari pihak laki-laki dan 10 dari pihak perempuan. Ahli waris dari pihak laki-laki ialah: (a) Anak laki-laki (al ibn). (b) Cucu laki-laki, yaitu anak lakilaki dan seterusnya kebawah (ibnul ibn) .(c) Bapak (al ab). (d)Datuk, yaitu bapak dari bapak (al jad). (e) Saudara laki-laki seibu sebapak (al akh as syqiq). (f)Saudara laki-laki sebapak (al akh liab). (g) Saudara laki-laki seibu (al akh lium). (h) Keponakan laki-laki seibu sebapak (ibnul akh as syaqiq). (i) Keponakan laki-laki sebapak (ibnul akh liab). (j) Paman seibu sebapak. (k) Paman sebapak (al ammu liab). (l)Sepupu laki-laki seibu sebapak (ibnul ammy as syaqiq). (m) Sepupu laki-laki sebapak (ibnul ammy liab). (n) Suami (az zauj). (o)Laki-laki yang memerdekakan, maksudnya adalah orang yang memerdekakan seorang hamba apabila sihamba tidak mempunyai ahli waris. 
Sedangkan ahli waris dari pihak perempuan adalah: (a)Anak perempuan (al bint). (b) Cucu perempuan (bintul ibn). (c) Ibu (al um). (d) Nenek, yaitu ibunya ibu ( al jaddatun). (e) Nenek dari pihak bapak (al jaddah minal ab). (f)Saudara perempuan seibu sebapak (al ukhtus syaqiq). (g) Saudara perempuan sebapak (al ukhtu liab).(h)Saudara perempuan seibu (al ukhtu lium). (i) Isteri (az zaujah). (j)Perempuan yang memerdekakan (al mu'tiqah).

Sedangkan bagian masing-masing ahli waris adalah isteri mendapat $1 / 4$ bagian apabila sipewaris mati tidak meninggalkan anak atau cucu, dan mendapat bagian 1/8 apabila sipewaris mempunyai anak atau cucu, dan isteri tidak pernah terhijab dari ahli waris. Adapun yang menjadi dasar hukum bagian isteri adalah firman Allah dalam surat An Nisa' ayat 12:

Terjemahnya :

"Para isteri memperoleh seperempat harta yang kamu tinggalkan, jika kamu tidak mempunyai anak, dan jika kamu mempunyai anak, maka isteri-isteri memperoleh seperdelapan dari harta yang kamu tinggalkan sesudah dipenuhi wasiat atau setelah dibayar hutang-hutangmu".

Suami mendapat $1 / 2$ bagian apabila pewaris tidak mempunyai anak dan mendapat $1 / 4$ bagian apabila pewaris mempunyai anak, berdasarkan firman Allah surat an Nisa' ayat 12: Terjemahnya :

"Dan bagimu (suami-suami) seperdua bagian dari harta yang ditinggalkan oleh isteri-isterimu, jika tidak mempunyai anak, dan jika ada anak maka kamu mendapat seperempat dari harta yang ditinggalkan sesudah dipenuhi wasiat dan sesudah dibayar hutang-hutangnya".

Sedangkan bagian anak perempuan adalah: (a) Seorang anak perempauan mendapat 1/2 bagian, apabila pewaris mempunyai anak laki - laki. (b) Dua anak perempauan atau lebih, mendapat $2 / 3$ bagian, apabila pewaris tidak mempunyai anak laki-laki. (c) Seorang anak perempuan atau lebih, apabila bersama dengan anak laki-laki, maka pembagiannya dua berbanding satu (anak laki-laki mendapat dua bagian dan anak perempuan mendapat satu bagian), hal ini berdasarkan firman Allah dalam Surat An Nisa’ Ayat 11

Terjemahnya :

"Jika anakmu, yaitu bagian seorang anak laki-laki sama dengan bagian dua orang anak perempuan".

Bagian anak laki-laki adalah: (a) Apabila hanya seorang anak laki-laki saja, maka dia mengambil semua warisan sebagai ashabah, jika tidak ada ahli waris dzawil furudz, namun jika ada ahli waris dzawil furudz maka ia hanya memperoleh ashabah (sisa) setelah dibagikan kepada ahli waris dzwil furudz tersebut (ashabah bin nafsih). (b) Apabila anak laki-laki dua orang atau lebih, dan tidak ada anak perempauan, serta ahli 
waris dzwil furudz yang lain, maka ia membagi rata harta warisan itu, namun jika ada anak perempuan, maka dibagi dua banding satu (ashabah bil ghair), berdasarkan surat Anisa' ayat 11 dan 12 tersebut.

Ibu dalam menerima pusaka/bagian harta waris adalah sebagai berikut: (a) Ibu mendapat seperenam, apabila pewaris meninggalkan anak. (b)Ibu mendapat sepertiga bagian, apabila pewaris tidak mempunyai anak.

Dan diantara ahli waris yang ada, apabila ada ibu maka yang dihijab ibu adalah nenek dari pihak ibu, yaitu ibu dari ibu dan seterusnya keatas. Nenek dari pihak bapak yaitu ibu dari bapak dan seterusnya keatas. Hal ini berdasarkan surat An Nisa' ayat 11: Terjemahnya

"Dan untuk dua orang ibu bapak, baginya seperenam dari harta yang ditinggalkan, jika pewaris itu mempunyai anak".

Bagian Bapak adalah: (a) Apabila sipewaris mempunyai anak laki-laki atau cucu dari anak laki-laki, maka bapak mendapat 1/6 dari harta peninggalan dan sisanya jatuh kepada anak laki-laki. (b) Apabila pewaris hanya meninggalkan bapak saja, maka bapak mengambil semua harta peninggalan dengan jalan ashabah. (c) Apabila pewaris meninggalkan ibu dan bapak, maka ibu mendapat 1/3 dan bapak mengambil 2/3 bagian.

Sedangkan bagian nenek adalah: (a)Apabila seorang pewaris meninggalkan seorang nenek saja, dan tidak meninggalkan ibu, maka nenek mendapat bagian 1/6. (b)Apabila seorang pewaris meninggalkan nenek lebih dari seorang dan tidak meninggalkan ibu, maka nenek mendapat 1/6 dibagi rata diantara nenek tersebut.

Menurut hukum waris Islam, orang yang tidak berhak mewaris adalah: (a) Pembunuh pewaris, berdasrkan hadtis yang diriwayatkan oleh At tirmidzi, Ibnu Majah, Abu Daud dan An Nasa'i. (b) Orang murtad, yaitu keluar dari agama Islam, berdasarkan hadits yang diriwayatkan oleh Abu Bardah. (c) Orang yang berbeda agama dengan pewaris, yaitu orang yang tidak menganut agama Islam atau kafir. (d)Anak zina, yaitu anak yang lahir karena hubungan diluar nikah, berdasarkan hadits yang diriwayatkan oleh At Tirmidzi (Hazairin, 1964: 57).

Perlu diketahui bahwa jika pewaris meninggalkan ibu, maka semua nenek terhalang, baik nenek dari pihak ibu sendiri maupun nenek dari pihak ayah (mahjub hirman). Dan jika semua ahli waris ada, maka yang berhak mendapat warisan adalah hanya anak (baik lakilaki maupun perempuan), ayah, ibu, dan janda atau duda sedangkan ahli waris yang lain terhalang (mahjub) (Pasal 174 Ayat (2) KHI). 


\section{SIMPULAN}

Dari uraian panjang yang telah dijelaskan pada bab sebelumnya maka kita dapat melihat tiga sisi hukum yang berbeda yang dianut oleh Negara Indonesia. Dimana orang Islam tunduk dan patuh pada hukum kewarisan Islam sedang orang non muslim tunduk pada hukum perdata (KUH Perdata) ataukah hukum adat.

Kemudian yang menjadi perbedaan antara sistem hukum waris Islam, hukum waris Adat dan hukum waris Perdata adalah bagian yang diperoleh oleh ahli waris lakilaki dan ahli waris perempuan. Dalam hukum waris Islam bagian ahli waris laki-laki mendapatkan dua kali bagian ahli waris perempuan. Sedangkan hukum waris adat bagian ahli waris perempuan seimbang atau sama rata dengan bagian ahli waris laki-laki adapun dalam hukum waris perdata sistem kewarisannya melalui pewarisan absentantio. (berdasarkan undang-undang) dan testamentair (wasiat).

Faktor-faktor yang mempengaruhi pelaksanaan pembagian warisan baik itu secara hukum Islam, hukum adat maupun hukum perdata memiliki beberapa perbedaan dan persamaan. Seperti pada hukum waris Islam faktor utama seseorang menjadi ahli waris yaitu adanya hubungan perkawinan, kekerabatan, hubungan memerdekakan budak dan hubungan agama ataukah sesama Islam.

Begitupun faktor-faktor yang menyebabkan seseorang terhalang untuk menjadi ahli waris masing-masing hukum memiliki perbedaan dan persamaan. Seperti pada hukum Islam faktor yang menjadi penghalang seseorang mendapatkan warisan yaitu pembunuhan baik secara sengaja maupun mirip sengaja. Selanjutnya adalah karena perbedaan agama, kemudian karena perbudakan dan yang terakhir adalah karena berbeda Negara atau kewarganegaraan.

\section{DAFTAR PUSTAKA}

Al-Quran al-Karim

Abdulkadir, Muhammad, Hukum Dan Penelitian Hukum, Bandung: Citra Aditya Bakti, 2004

Afandi, Ali, Hukum Waris, Hukum Keluarga, Hukum Pembuktian, Jakarta: Rineka Cipta, 1997

Anshori, Abdul Ghofur. Hukum Kewarisan Islam di Indonesia Eksistensi dan Adabtabilitas, Edisi 1, Cetakan 1, Yogyakarta: Gadjah Mada University Press, 2012.

Ash-Shiddieqy, Muhammad Hasbi, Teungku. Koleksi Hadits-Hadits Hukum 3, Semarang : Pustaka Rezki Putra, 2011.

Ash-Shiddieqy, Teungku M. Hasbi, Fiqh Mawaris, Semarang: Pustaka Rizqi Putra, 1997

Dahlan, Abd.Rahman, Ushul Fiqh, Edisi 1, Cetakan 1, Jakarta : Amzah, 2010 
Ela Khalifa, Muhammad Thaha, Hukum Waris Pembagian Warisan Berdasarkan Syariat Islam, Cetakan 1, Solo : Tiga Serangkai, 2007.

Ghofur Anshori, Abdul, Hukum Kewarisan Islam di Indonesia, Yogyakarta: Ekonisia, 2002

Habiburrahman, Rekonstruksi Hukum Kewarisan Islam di Indonesia, Edisi 1, Cetakan 1, Jakarta : Kencana, 2011.

Hadikusuma, Hilman, Hukum Waris Adat, Cetakan 7, Jakarta: PT. Citra Aditya Bakti, 2003

Ibrahim, Jhonny, Teori dan Metodologi Penelitian Hukum Normatif, Malang: Bayumedia Publishing, 2006

Idrus, Muhammad, Metode Penelitian Ilmu Sosial Pendekatan Kualitatif dan Kuantitatif, Edisi 2, Jakarta: Erlangga, 2009.

Mardani, Hukum Kewarisan dalam Islam di Indonesia, Edisi 1, Cetakan 1, Jakarta : Rajawali Pers, 2014.

Muhibbin, Mohammad, Abdul, Wahid, Hukum Kewarisan Islam Sebagai Pembaruan Hukum Positif di Indonesia, Edisi 1, Cetakan 2, Jakarta : Sinar Grafika, 2011.

Noor, Juliansyah, Metodologi Penelitian Skripsi, Tesis, Desertasi, dan Karya Ilmiah, Edisi 1, Cetakan 1, Jakarta : Kencana, 2011.

Putra, Nusa, Research \& Development Penelitian dan Pengembangan : Suatu Pengantar, Edisi 1, Cetakan 1, Jakarta : Rajawali Pers, 2011.

Qadri, AA, Sebuah Potret Teori dan Praktek Keadilan Dalam Sejarah Pemerintahan Muslim, Yogyakarta: PLP2MP 1987

Quthb, Sayyid, Keadilan Sosial Dalam Islam, Bandung: Pustaka 1994

Rahman, Asymuni.A., et.al. Ilmu Fiqhi 3, Cetakan 2, t.d.

Ramulyo, Idris, Perbandingan Hukum Kewarisan Islam dengan Kewarisan Kitab Undang-Undang Hukum Perdata, Cetakan 1, Jakarta: Sinar Grafika, 2004.

Republik Indonesia. "Undang-Undang RI Nomor 1 Tahun 1974 tentang Perkawinan dan Buku II Kompilasi Hukum Islam tentang Hukum Kewarisan. Bandung : Citra Umbara, t,th.

Rofiq, Ahmad, Fiqhi Mawaris, Edisi revisi, Cetakan 5, Jakarta : Rajawali Pers, 2012.

Rofiq, Ahmad, Fiqh Mawaris, Jakarta: Raja Grafindo Persada, 2002

Samosir, Djamat, Hukum Adat, Eksistensi Dalam Dinamika Perkembangan Hukum di Indonesia, Cetakan 1, Bandung: Nuansa Aulia, 2013

Setiadi,Tholib, Intisari HUkum Adat Indonesia dalam Kajian Kepustakaan, Cetakan 3, Bandung: Alfabeta, 2013

Soekanto, Soerjono, Sri, Mamudji, Penelitian Hukum Normatif Tinjauan Singkat, Jakarta: Rajawali Pers, 2006 
Soraya Bugaib, Andi, Buku Ajar Kuliah Kewarisan.t.p.

Suhrawardi K. Lubis, Komis Simanjuntak, Hukum Waris Islam, Jakarta: Sinar Grafika, 1992

Sukandarrumidi, Metodologi Penelitian Petunjuk Peraktis Untuk Peneliti Pemula, Cetakan III, Yogyakarta : Gadjah Mada University Press, 2006.

Syarifuddin, Amir, Hukum Kewarisan Islam, Edisi 1, Cetakan IV, Jakarta : Kencana 2012.

Utomo, laksanto, Hukum Adat, Cetakan 1,Jakarta: PT.Raja Grafindo Persada,2016

Yunus, A.Assaad, Pokok-Pokok Hukum Kewarisan Islam (Faraidh), Jakarta: Al Qushwa, 1992. 